\title{
Urfa Merkez Ağzı ile Azerbaycan Türkçesi arasındaki ortak özellikler
}

\section{İsmail GÜNEŞ}

\begin{abstract}
APA: Güneş, İ. (2020). Urfa Merkez Ağzı ile Azerbaycan Türkçesi arasındaki ortak özellikler. RumeliDE Dil ve Edebiyat Araştırmaları Dergisi, (19), 242-264. DOI: 10.2900o/rumelide.752300.
\end{abstract}

\section{$\ddot{O} \mathbf{z}$}

Türkçenin başlangıçtan günümüze kadar geçirmiş olduğu merhalelerin ve tarihi dönemlerle bölgelere göre gösterdiği dil özelliklerinin tespit edilmesinde Anadolu ağızları önemli bir veri kaynağ durumundadır. Hâlihazırda Türkiye Türkçesi ağızlarından bazılarının yeteri kadar, bazılarının ise henüz incelenmemiş durumda olması Türkiye Türkçesi ağız atlaslarının hazırlanmasını olumsuz yönde etkilemektedir. Ağız atlasları, bir bölgede konuşulan ağzın ses, şekil ve söz dizimi özellikleri ile birlikte söz varlığına dair önemli bilgiler sunmaktadır. Bu nedenle ağız atlaslarının içerdiği malzemenin dil bilimsel yönü dışında halk bilimini ilgilendiren sosyo-kültürel bir niteliği de vardır. Anadolu ağızlarının dil özelliklerinin ayrıntılı bir şekilde belirlenmesi bu bağlamda oldukça önemlidir. Batı Türkçesinin doğu kolunu meydana getiren Azerbaycan Türkçesinin dil özellikleri, Anadolu sahasında Azerbaycan'a nispeten daha yakın olan Doğu Anadolu bölgesinde de görülmektedir. Urfa ağzı, Anadolu ağızlarının tasnifi çalışmalarında Doğu grubu ağızlarına dahil edilmiştir. Dil özellikleri bakımından ülke sınırlarının ötesine uzanan Urfa ağzı, Azerbaycan ve IrakTürkmen Türkçeleriyle kesişmekte ve benzerlikler göstermektedir. Güneydoğu Anadolu bölgesinde yer alan Urfa, aynı zamanda doğu grubu Anadolu ağızlarını Irak Türkmen ağızlarıyla birleştiren bir geçiş noktasıdır. Bir ağız bölgesinin morfolojik ve fonetik açıdan analizinin yapılmasında o ağız bölgesini etkileyen konuşma ve yazı dilleriyle yapılacak mukayeseli çalışmalar önem arz etmektedir. Bu çalışmada Azerbaycan Türkçesi ile Urfa Merkez ağzı, morfolojik ve fonetik açıdan karşılaştırılarak her iki dil bölgesinde tespit edilen ortak unsurlar ortaya konmuştur.

Anahtar kelimeler: Urfa ağzı, Azerbaycan Türkçesi, Urfa, Azerbaycan, ağız

\section{The common features between Urfa center dialect and Azerbaijani Turkish}

\begin{abstract}
The Anatolian dialects are an important source of data in determining the stage of the Turkish language from the beginning to the present and the linguistic characteristics of the regions. At present some of the Turkey Turkish dialects are not investigated adequately and some of them have not investigated yet thus this situation affects the preparation of the Turkey Turkish dialects' atlas adversely. Dialect atlases, provide important information with the lexicology about the sound, shape and syntax features of the local language spoken in a region. For this reason, the material that the dialect atlases contain has a socio-cultural quality that concerns folklore apart from its linguistic aspect. The detailed determination of the linguistic features of the Anatolian dialects is very important in this context. The linguistic features of Azerbaijani Turkish, which constitutes the eastern branch of Western Turkish, are also observed in the eastern Anatolian region, which is relatively closer to Azerbaijan in the Anatolian field. The Urfa dialect which extends beyond the borders of the
\end{abstract}

1 Dr. Öğr. Üyesi, Aksaray Üniversitesi, Fen Edebiyat Fakültesi, Türk Dili ve Edebiyatı Bölümü (Aksaray, Türkiye), ismailgunes@yahoo.com, ORCID ID: 00oo-0002-4563-4950 [Makale kaylt tarihi: 12.05.2020-kabul tarihi: 20.06.2020; DOI: $10.29000 /$ rumelide.752300] 
country in terms of language characteristics and shows similarities with Azerbaijan and IraqiTurkmen Turkish. Urfa, located in the Southeastern Anatolia region, is also a crossing point that connects the eastern group Anatolian dialects with Iraqi Turkmen dialects. Morphological and phonetic analysis of a dialect region is important for the analysis of speech and writing languages that affect that dialect region. In this study, the common elements identified in both language regions were compared by comparing the morphology and phonetic aspects of the center Urfa dialect which is under the influence of Azerbaijani Turkish.

Keywords: Urfa dialect, Azerbaijani Turkish, Urfa, Azerbaijan, dialect

\section{Giriş}

XI. yüzyılda Orta Asya'dan batıya doğru göç eden Türk toplulukları, başta Anadolu olmak üzere Azerbaycan, Irak ve Suriye coğrafyasına yerleşmeye başlamıştır. Selçuklu hükümdarı Alpaslan’ın 1064'te bölgeye düzenlediği sefer ile tamamen Türk hâkimiyetine giren Azerbaycan, Büyük Selçuklu Devletinin bir eyaleti haline gelmiştir (Kafesoğlu, 1972: 34-43). Azerbaycan'ın Selçuklu topraklarına katılmasıyla bölge, Oğuzların öbekler halinde buraya yerleşmelerine sahne olmuştur.

Büyük Selçuklu Devletinden sonra Irak Selçuklularının ve İldenizliler Hanedanı’nın egemenliği altına giren Azerbaycan, XII.-XIV. yüzyllar arasında Moğollar, Harezmşahlar ve Timurluların idaresine girmiştir. Moğol istilasından sonra Karakoyunlular ve Akkoyunlular'ın yönetimi altına giren Azerbaycan, Akkoyunluların XVI. yüzyılda yıkılmasından sonra tamamen Safevî Devletinin eline geçmiştir. 1747 yllında Nâdir Şâh'ın ölümüne kadar Osmanlı Devletiyle Safeviler arasında zaman zaman el değiştiren Azerbaycan'da XVIII. yüzyılın başlarından itibaren Ruslar etkili olmaya başlamıştır. 18051813 tarihleri arasında Rus-İran mücadelelerine sahne olan Azerbaycan, 1828 yllında Türkmençay Anlaşması'yla Kuzey ve Güney Azerbaycan olmak üzere ikiye ayrılmıştır (Saray, 1993: 11-20). 1918'de Mehmed Emin Resulzâde'nin önderliğinde Kuzey Azerbaycan'da kurulan Azerbaycan Demokratik Cumhuriyeti uzun ömürlü olmamış, 1920'de Sovyetler Birliğinin bir parçası olmuştur. 1991'de Sovyetler Birliğinin dağılmasıyla Azerbaycan Cumhuriyeti bağımsızlı̆̆ını ilan etmiştir (Özkan, 2000: 92).

Büyük çoğunluğunu Oğuzların oluşturduğu Türk topluluklarının, X.-XI. yüzyllardan itibaren çeşitli nedenlerle batıya doğru gerçekleştirdikleri göçler, XIII. yüzyıla kadar tek bir kol halinde varlığını devam ettiren Türk dilinin dallanmasına ve farklı yazı dillerinin ortaya çıkmasına zemin hazırlamıştır. Oğuzların baştan beri hatırı sayılır bir sözlü geleneğe sahip olmaları, Anadolu Selçuklu Devletinin mirasını devralan Anadolu beyliklerinin Türkçe konusundaki duyarlılıkları, Azerbaycan ve Anadolu sahasında Oğuzca esasında yeni bir yazı dilinin oluşmasına zemin oluşturmuştur. Batıya göç eden Oğuzların kendi ağız özellikleri temelinde meydana getirdikleri bu yazı dili, Türk dili tarihinde Batı Türkçesi olarak adlandırılmaktadır.

Batı Türkçesi, XIV. yüzyıldan itibaren farklılaşmaya başlamış ve XVII. yüzyılda coğrafya ekseninde ikiye ayrılmıştır. Böylelikle Azerbaycan ve Doğu Anadolu'da Azerbaycan Türkçesi, Osmanlı sahasında ise Osmanlı Türkçesi iki ayrı yazı dili durumuna gelmiştir (Ergin, 1993: 14).

Azerbaycan Türkçesi, Batı Türkçesinin doğu kolunu meydana getiren yazı dilidir. Azerbaycan sahası, dil coğrafyası bakımından Doğu Anadolu, Güney Kafkasya ve Kafkas Azerbaycanı, İran Azerbaycanı, Kerkük ve Irak-Suriye Türkleri bölgelerini kapsar (Ergin, 1971: VIII). Azerbaycan Türkçesi, Kuzey Azerbaycan'da, kısmen Güney Azerbaycan ve Kerkük'te yazı dili durumundadır. Bu bölgelerin yanı sıra, 
Güney Kafkasya ve Doğu Anadolu'da ise konuşma dili düzeyinde varlığını devam ettirmektedir (Ergin, 1971: IX).

\section{Urfa}

Güneydoğu Anadolu Bölgesi’nde bulunan ve yaklaşı 10.000 ylllık tarihi geçmişe sahip olan Şanlıurfa, bu uzun süreçte birçok kültür ve medeniyete beşiklik etmiştir. Yüzyllarca ticaret kervanlarının kullandığı bir rota olmakla birlikte Doğu ile Batı kültürleri arasında bir köprü vazifesi gören İpek Yolu güzergâhında yer alan Şanlıurfa, farklı uygarlıkların kesiştiği bir yer olmuştur. 1094 yılında Selçuklu topraklarına dâhil olan Urfa, 1098'de Haçlı Kontluğunun idaresi altına girmiştir. Daha sonra Eyyubi, Memluk, Türkmen aşiretleri, Timur Devleti, Akkoyunlular, Dulkadirbeyliği, Safevilerin egemenliği altına giren Urfa, 1516’da Osmanlı topraklarına katılmıştır. 1919 yllında önce İngilizlerin, sonrasında ise Fransızların işgaline uğrayan Urfa, 11 Nisan 1920'de milli mücadelesini vererek işgalden kurtulmuş ve cumhuriyetten sonra 1924'te il olmuştur. Urfa'ya, Kurtuluş Savaşı'nda halkının göstermiş olduğu kahramanlıktan dolayı, 1984 yılında çıkartılan bir yasa ile "Şanlı" unvanı verilmiştir (Aslan, 2017: 14).

\section{Urfa ağzı}

Anadolu ağızlarıyla ilgili yapılan tasnif çalışmalarında Urfa ağzı (Birecik ve Halfeti hariç) doğu grubu ağızlarına dâhil edilmiştir. Doğu grubu Anadolu ağızları, güneyde ve doğuda siyasi sınırların dışına çıkarak Azerbaycan ve Irak-Türkmen ağızlarıyla birleşir. Güneydoğu Anadolu bölgesinde yer alan Urfa, doğu grubu Anadolu ağızlarını Irak Türkmen ağızlarıyla birleştiren bir geçiş bölgesidir (Karahan, 1996: 54). Dil özellikleri bakımından genel olarak standart yazı diline uygunluk gösteren Urfa Merkez ağzı, bunun yanı sıra, Azerbaycan Türkçesi ile Irak-Kerkük Türkmen Türkçesiyle yaklaşan bir görüntü çizer.

\section{3. İnceleme}

Urfa ağzı ile Azerbaycan Türkçesinin ortak yönlerinin ele alınacağı bu çalışmada, Urfa Merkez ağzı esas alınmıştır. Urfa'nın ilçelerinin tamamı ağız özellikleri açısından incelenmediği için ilçe ağızları bu çalışmaya dâhil edilmemiştir. Urfa Merkez ağzıyla ilgili şu ana kadar akademik düzeyde yapılmış iki

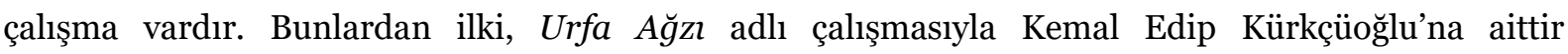
(Kürkçüoğlu, 1991). Diğeri ise Sadettin Özçelik tarafından hazırlanan Urfa Merkez Ağzı adlı çalışmadır (Özçelik, 1997). Bu çalışmada Urfa Merkez ağzı ile Azerbaycan Türkçesinin ortak yönleri ele alınacak, tespit edilen benzerlikler örnekler üzerinde gösterilecektir. Kürkçüoğlu’nun eseri, hacim olarak küçük olması ve çok az sayıda metin içermesinden dolayı karşılaştırma çalışması için tercih edilmemiştir. Karşılaştırma için kullanılan Urfa ağzına ait örnekler, Özçelik’in Urfa Merkez A ğzı adlı çalışmasından alıntılanmıştır.

\subsection{Ses bilgisinde görülen ortak özellikler}

\subsubsection{Kalınlık-incelik uyumu}

Türk dilinde Eski Türkçeden beri sağlam olan kalınlık-incelik uyumunun işleyişi, Azerbaycan Türkçesinde daha ileri bir düzeydedir. Türkiye Türkçesinde uyum dışı kalmış Türkçe kökenli bazı kelimelerle Arapça ve Farsça alıntı pek çok kelime, farklı ses olayları sonucu uyuma girmiş durumdadır. Anadolu ağızlarında da kalınlık-incelik uyumu, standart yazı diline göre daha çok işler durumdadır. 
Doğu grubu ağızları içinde yer alan Urfa ağzında yer yer bozulmalar olmasına rağmen, uyumun ağırlıklı olarak işlediği görülmektedir. Eski Türkçe ve Eski Anadolu Türkçesinde uyuma bağlı olduğu halde günümüz yazı dilinde uyum dışına çıkan hani, hangi, hangisi gibi kelimeler de Urfa ağzında hanı, hangı, hangısı şeklinde uyuma girmiştir (Özçelik, 1997: 20).

xəste (< Far. haste):

Sevirəm o yaşl, xəstə gözünü, / Sevirəm o şirin, dadlı sözünü (Çobanzade, 2011: 107).

onlar ḩeste olmışlar. hestelígínden sonra achg̀ olmış. acda şè olmışlar... (180).

dəfə (< Ar. defa):

O gündən sonra əsəd hər dəfə Xəzangülü görənde bircə dəfə gözlərini qirpard, yəni "Mən sənə qurban olum." (Hacizadə, 2004: 276).

Yanı ar ḩadaşlarımızdan ha naza çeken var, ne var dèyenler var ha. çünkí o televizyon ḳarşısında bir dehfe şartlanmışı h (174).

fəqir (< Ar. faḳir):

Zəifsən qüvvət verən, / Fəqirsən qanad gərən, / Bizlərik, sənin kimi / Bu yurdda ömür sürən (Çobanzade, 2011: 29).

Ėle feḳir düşmíşler ki nana mıḥtac... (226).

rəhmət (< Ar. rahmet):

Nikolaya ona görə rəhmət oxuyur ki, bizdən soldat aparmayıbder (Mirəhmov, 2006: 201).

He reḥmete gèttí, ciğara verím içi mísíz? (151).

3.1.2. Önlüleşme: /e/ </a/

Azerbaycan Türkçesinde, Arapça ve Farsça kökenli birçok alıntı kelimenin yapısındaki kısa ve kalın ünlülerin incelmesiyle bu kelimeler, kalınlık-incelik uyumuna uygun yapıya dönüşmüştür. Bu incelme olayı, Urfa ağzını Azerbaycan Türkçesine yaklaştırır.

dəqiqə (< Ar. daḳiḳa):

On dəqiqədən sonra Nino nazik əllərini mənə uzadırdı (Səid, 2006: 79).

On deḳkede üç tene ḳurban kèsílī (172).

zəhmət (< Ar. zahmet)

Qoy zəhmət çəkib hamı kimi vaxtında gəlib-getsin işə (Hacızadə, 2004: 170).

Çoh zeḥmet çekmişsler, ḳurt girmiş (180). 
qəzəb (< Ar. ġażab):

Va mahz hamin masiyatin naticasidir ki, indi sanin da bu camaata qazəbin tutub (Memmedquluzada, 2004: 19).

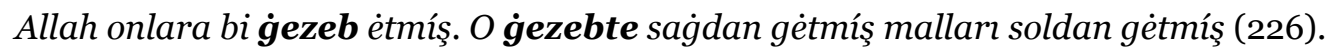

xəfif $(<$ Ar. hafif)

Üzünə xəfiff qızartı çökmüş Xatirə müəllimə baxışlarını uzaqlara dikmişdi (Mirəhmov, 2006: 67).

Onı salçalı hefif bir su yaparsan (206).

xətir $(<$ Ar. ḩațīr)

Yel tikan qovur, / Türkü oxuyur, / Xətrimi sorur, /xətrimi sorur (Çobanzadə, 2011: 105).

Ya'nı bèle herkesí cem'etmah, toplanmah, hal hetír sormah (175).

\subsubsection{Artlılaşma: $/ \mathbf{a} /</ \mathbf{e} /$}

Azerbaycan Türkçesinde Arapça ve Farsça kökenli alıntı kelimelerin yapısında kalınlık-incelik uyumu bağlamında görülen bir diğer ses olayı da artlılaşmadır. Alıntı kelimeler, önlüleşme olayında olduğu gibi artlılaşma yoluyla da uyuma bağlanmış durumdadır. Urfa Merkez ağzında -özellikle Arapça ve Farsça kökenli alıntı kelimelerde- çoklukla görülen artlılaşma olayı, Urfa Merkez ağzıyla Azerbaycan Türkçesi arasındaki ortak özelliklerden biridir.

salam $(<$ Ar. selām):

Erməni də başını çevirib, başı ilə dostcasına salam verdi (Səid, 2006: 64).

Yarıma sálám èdın, / ölmemíşem saġam ben (161).

$\operatorname{maraq}(<$ Ar. merāk):

Çingiz Terekuloviç öz həyatından başqa maraql hekayətlər də danışdı (Mirəhmov, 2006: 146).

‘Ali abè de maraḳh balḳonu müse'it (166).

$\operatorname{avara}(<$ Far. āvāre):

Nəticədə isə avara bir boşboğaz kimi qahrıq arxada (Bünyadzadə, 2005: 167).

Ya bením bu 'avarahìgm nère gidī 'avarahı̇ım? (153). 


\title{
3.1.4. Ünsüz ötümlüleşmesi
}

\author{
3.1.4.1. $/-\dot{\mathrm{g}} /</-\mathrm{k} / \mathbf{2}$
}

Eski Türkçede kelime başındaki kalın / $k$ / sesinin ötümlüleşerek / $g$ / olması Oğuzcanın karakteristik bir özelliğidir. Azerbaycan Türkçesinde söz başındaki kalın $/ k /$ sesiyle birden fazla heceli kelimelerin sonundaki kalın $/ k$ / sesleri, art damak / $g$ / sesine dönüşmüştür (Kartallığlu ve Yıldırım, 2007: 181). Urfa Merkez ağzında ise $/ \dot{g} /</ k /$ ötümlüleşmesi söz içinde ve söz sonunda görülmektedir.

\section{Azerbaycan Türkçesi:}

qonaq (< konak): $O$, möhtərəm qonaq kimi kürsüyə əyləşərək məni xoş bir əda ilə salamladı (Rihani, 2016: 189).

ayaq (< ayak): Jqli-huşum əldən alar, eşqdən çəkdim ayaq, Bu Nəfəs halın yenə quldı pərişan gözlərin (Nəfəs, 2010: 17).

quyruq (< kuyruk): Bə’zinə diş qıcıdıb, bə’zinə quyruq bularıq, / Bizə hər kəs çörək atsa, onu təqdir edərik! (Sabir, 2004: 270)

daraq (< tarak): Sonra birdən yadına düşür ki, daraq taxçadakı boxçanın içindedi. Amma daha hara keçər (Acaloğlu ve Bəydili , 2005: 76).

\section{Urfa Merkez A ̆gzz:}

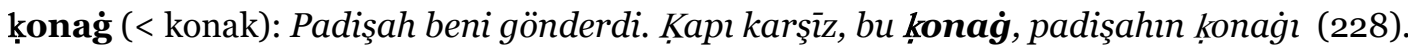

ayag (< ayak): Temsili şíndí bením üç ayà̇ veri, senínki de ikki ayag veri (181).

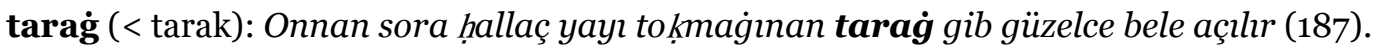

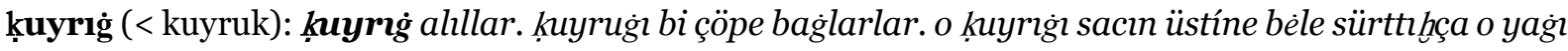
bèle erír (200).

\subsubsection{2. $/ \mathbf{d}-/</ \mathrm{t}-/$}

Eski Türkçede söz başında bulunan /t/ sesi, Eski Anadolu Türkçesi döneminde ötümlüleşerek /d/ olmuştur. Batı Türkçesinin batı ve doğu kollarını oluşturan Osmanlı ve Azerbaycan sahaları arasında $/ d /</ t /$ ötümlüleşmesi bakımından fark vardır (Ergin, 1993: 88). Anadolu sahasında, Osmanlıcada varlığını devam ettiren söz başı $/ d /$ sesi, devrenin sonlarına doğru yeniden ötümsüzleşerek $/ t /$ olmuştur.

Azerbaycan sahasında ise bazı kelimelerde / $d /$ sesinde yeniden bir ötümsüzleşme olmamış, /d/ sesi kullanılmaya devam etmiştir.

Eski Anadolu Türkçesinden itibaren Batı Türkçesinde görülen $/ d-/</ t-/$ ötümlüleşmesi olayı, Anadolu ağızlarında standart yazı diline göre daha çok muhafaza edilmiştir. Doğu grubu ağızları içerisinde yer

Azerbaycan Türkçesinde kalın / $g$ / sesi, /q/ işaretiyle gösterildiği için Azerbaycan Türkçesi için yapılan alıntılarda kalın $/ g /$ sesi, $/ q$ / ile gösterilmiştir. 
alan Urfa Merkez ağzında da Azerbaycan Türkçesine benzer bir durum söz konusudur. $/ d-/</ t-/$ ötümlüleşmesi söz başında ve söz sonunda görülebilmektedir.

\section{Azerbaycan Türkçesi:}

daran- (< taran-): Geri baxdım: durur anam / Gür saçları da daranmış (Zanet, 2010: 41).

dart- (< tart-): İtlərin başım qatar birisi / Quzunu dərəyə dartar birisi... (Araz, 2004: 145).

daş < (< taş): Mələyə-mələyə quzu bulaqlar / Daşlarnn dibində yetim qaldılar (Araz, 2004: 151).

dırnaq (< tırnak): Sızanaqları dernaqlarmın arasına alıb sıxır, sifətini qanadır (Elçin, 2005: 96).

\section{Urfa Merkez Ăgzz:}

daşın- (< taşın-): Bunlar kimdírler, bu eve daşınmışlar (228).

diskin- (< tiksin-): Daha ḳablar kirli díye dískíniken bah̆i ki ne bahsın (229).

datlı (< tatlı): Çi kífteler olur. Dathlar yapılır (195).

duzla- (tuzla-): Pathcan firna atılır, duzlar sögílme yaparıh (190).

\subsection{5. Ünsüz sızıcılaşması: /x (h) / </k $/$}

Söz içinde ve söz sonunda görülen $/ h /</ k /$ değişmesi, Batı Türkçesinde daha çok Eski Anadolu Türkçesi döneminde görülür. Eski Anadolu Türkçesi devresinden sonra Osmanlı sahası, ağırlıklı olarak / $k /$ 'li kullanıma dönerken, Azerbaycan sahasında Eski Anadolu Türkçesinin devamı niteliğinde / $h$ /'li şekiller kullanılmaya devam etmiş ve yaygınlaşmıştır. Azerbaycan Türkçesinde kelime içi ve sonunda çoklukla görülen $/ h /</ k$ sszıcılaşması, doğu grubu Anadolu ağızları için karakteristik bir ses olayıdır (Karahan, 1996: 56). Doğu grubu ağızları içerisinde yer alan Urfa Merkez ağzında da / h/ sesi oldukça yaygındır.

\section{Azerbaycan Türkçesi:}

Qorxar... İşi çoxdur... Azca ağlad, / Qorxduki, eşidib kədərlənərsən (Araz, 2004: 51).

Saxlayıb müxtəlif evlardə miskin, evindən saldılar onu didərgin (Qüdsi, 2005: 227).

Tanısan Batunu, Çingizi yaxşı, / Axardı gözünün o qanlı yaşı (Çobanzadə, 2011: 74).

Sən öz mənliyinin dar sarayından / Kənara çıxmasan, ey dostum, inan, (Vazeh, 2004: 40).

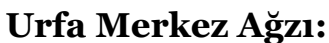

Sa ìd dèdí: "Baba ben utandım. Ėyi bahamadım." (165).

Absşam üzerí herkes tükeníní kitledígí zaman tükkenínín zırını zıbırını sípírī (155).

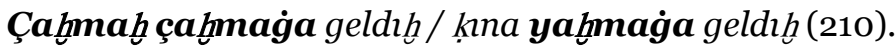

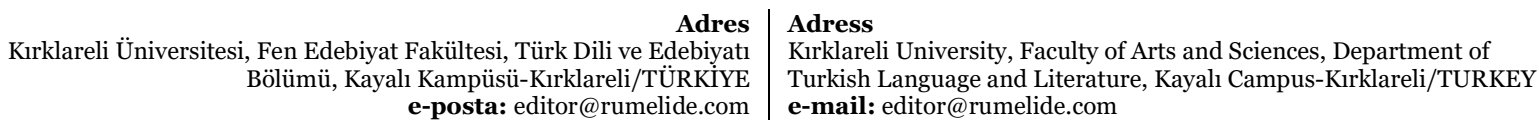




\subsection{6. Ünsüz ötümsüzleşmesi: /p-/ < /b-/}

Eski Türkçede kimi kelimelerde ön ses durumunda bulunan /b/ sesinin Batı Türkçesinde ötümsüzleşerek $/ p /$ olma seyri, Osmanlı ve Azerbaycan sahalarında farklı şekillerde cereyan etmiştir. Osmanlıcada ötümsüzleşme sonucu ön seste / $/ p$ sesiyle kullanılan bir kelime Azerbaycan Türkçesinde /b/, bazen de Azerbaycan Türkçesinde ötümsüzleşme sonucu / $p$ / ile kullanılan bir kelime Osmanlı sahasında /b/ile kullanılmıştır (Ergin, 1993: 80).

Urfa Merkez ağzında, Türkiye Türkçesi standart yazı dilinde bazı kelimelerin başında bulunan / $b$ / sesi, Azerbaycan Türkçesinde olduğu gibi ötümsüzleşerek /p/'ye değişmiştir.

\section{Azerbaycan Türkçesi:}

palçıq (< balçık): Qalaca küncünə qısılan şahın / Xalqı palçıq kimi tapdalamıbdı (Araz, 2004: 188).

pozul- (< bozul-): Qafqaz xalqları arasında məhəbbətdən danışanda Məhəmməd Heydərin əhvah pozuldu (Səid, 2006: 87).

paxla (< bakla): Məsəlan: hübubat, qəbilden buğda, maş, noxud, paxla, çaltik, marcimək, küncüt, çətənə... (Məmmədquluzadə, 2004: 160).

\section{Urfa Merkez A ̆gzı:}

pıçah̆ (< bıçak): Bèle ustıra gibi bir pıçah̆ elínde ḥazır, bunın boynına sürmaġa başlar (145).

paḳlava (< baklava): Paḳlava dílímí şėden keserler, pıçaḩdan (200).

\subsubsection{Sürekli ünsüzler arasında değişme}

\subsubsection{1. $/ \mathbf{l} /</ \mathbf{r} /$}

Türkçede söyleyiş zorluğu bulunan akıcı / $r$ / sesi, kimi kelimelerde yine akıcı bir ünsüz olan $/ l$ sesine değişebilir. Özellikle Anadolu ağızlarında ve konuşma dilinde yaygın olan bu ünsüz değişmesi, Azerbaycan Türkçesi ile Urfa Merkez ağzının sahip olduğu ortak özelliklerden biridir.

saral- (< sarar-):

Jttar yarı göran kimi zəfərantək saraldı / Çırpınaraq qalbi birdən onu sonsuz bir dərd aldı (Qüdsi, 2005: 152).

Hastayam lemun kímín / saraldım onın kímín / ne gavır ne müslíman / olmasın bením kímin (235).

3.1.7.2. $/ \mathbf{n} /</ \mathbf{m} /$

Urfa Merkez ağzı ile Azerbaycan Türkçesi arasında ses bilgisi açısından ortak olan özelliklerden biri de çok yaygın olmayan $/ n /</ m /$ ünsüz değişmesi olayıdır.

indi / şíndí ( $<$ şimdi): 


\section{Azerbaycan Türkçesi:}

Baxışı sənin qəlbini titrədən o bəxtəvər qız indi neynir, görəsən? (Bünyadzadə, 2005: 204)

Lakin indi mən heç biri döyüşmək istəməyən iki qafqazlının arasında oturmuşam (Səid, 2006: 66).

\section{Urfa Merkez Ağzı:}

Davul çaldıh̆, ikkí gün. Mevlüd yapmadıh. Şíndí olsa yaparıh (181).

Bení şíndí bi tenesí bi milyona tutsa daş taşıtsın, ben bu tükení bura h̆ram (152).

\subsubsection{Göçüşme (Metatez)}

Kelime içerisindeki iki ünsüzün yer değiştirmesi olayı olan göçüşme, Azerbaycan Türkçesiyle Anadolu ağızlarında sıkça görülen bir ses olayıdır. Urfa Merkez ağzında / $r$ / ünsüzünün bulunduğu kelimelerde göçüşme olayı daha çok görülmektedir.

\section{Azerbaycan Türkçesi:}

Bu nəfs bir parça torpaq, yaxud satılacaq və girov qoyulacaq mal deyil (Rihani, 2016: 127).

Torpaqdan yenicə dirçəlməyə başlayan az qala torpaqdan seçilməyən qırmızı yarpaqlar quşəppəyini quş kimi dənlərdik (Bünyadzadə, 2005: 100).

Çılpaq qayasına, soyuq daşına / Yağışlı dumanlar yetişə bilmir (Araz, 2004: 129).

Həyətdə qeybətləşən arvadlar səslərini kəsib bir-birilərinin üzünə baxdılar (Bünyadzadə, 2005: 11).

Bir dəfə mən gecə bu iniltilərə və xorultulara yuxudan ayzldım və bərk dilxor oldum (Mirəhmov, 2006: 292).

\section{Urfa Merkez Ağzı:}

O zamana ḳeder Cebrayil 'aleyhisselam geldí dèdí ki: “Eliyi torpà̇a vur baḥm.”(247).

Bi melmekete gelmíş̧ ȟ̉. Şíndí bízím ḷaz gelín etmaḩ zamanımız mı dèyī (233).

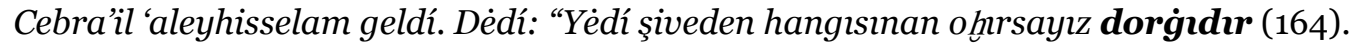

Yani bunlar gider ister. Ya dayısının arvad, ya 'emísínín arvadı.. İşte bèle (193).

Sení pehriz èdī. Siye ‘ilac yazī.. (184).

\subsection{9. Ünsüz ikizleşmesi}

İç seste iki ünlü arasında bulunan ve vurgulu olan ikinci hecenin başındaki ünsüzlerin açık hecenin zayıflığını kapatmak üzere tekrarlanmasıyla ortaya çıkan ünsüz ikizleşmesi, Türkiye Türkçesinde birkaç istisna dışında görülmez (Karaağaç, 2012: 80). Buna karşıllk çağdaş lehçelerden Azerbaycan 
Türkçesinde pekiştirme, ses düşmesi ya da uzun ünlülerin kısalması gibi etmenlere bağlı olarak meydana gelen bazı ikizleşme örnekleri görülmektedir (Yalçın, 2018: 161). Azerbaycan etkisinin görüldüğü doğu grubu Anadolu ağızları arasında yer alan Urfa Merkez ağzında da benzer şekilde ünsüz ikizleşmelerine rastlanmaktadır.

\section{Azerbaycan Türkçesi:}

Yeddi yalan yazdınız / Balkandandır soyumuz, kökümüz... (Zanet, 2010: 15).

Dənizdə ki, doqquz fələk sədəfdir, / Səndəki dörd gövhər sənə şərəfdir (Cami, 2004: 180).

Təpərsiz, cəsarətsiz səslə gülsatan saqqalh, qırmızıyanaq kişiyə müraciət eləyib (Hacızadə, 2004: 277).

Doğmaca qardaşı çaqqal qurd ilə, / Qəsdən el içində gəzirlər elə (Bünyadzadə, 2005: 29).

\section{Urfa Merkez A ̆gzı:}

Bazartesı bunın ikkísí bitmisş, bu dügmeleríní göttírmişem, evde tikmíşem (154).

Ottnz bin lèra keder tutar, bu ḳonışma, bèle nası tèlí çektímse ordan (155).

Ayaġa ḳa ḩacah daha taḳatım ḳalmamış. Ellíyedí ellísekkíz yaşındayam (154).

İçersíne girdí. Büttín arındı ve çı h̆t (247).

\subsubsection{Aykırılaşma}

Benzeşmenin tam tersi olan aykırılaşma olayı, boğumlanma noktaları aynı olan iki ünsüzden birinin boğumlanma yeri farklı olan bir ünsüze dönüşmesidir. Azerbaycan Türkçesinde ve Urfa Merkez ağzında benzeşmeye göre daha az görülen bir ses olayıdır.

hambal < (Ar. hammal):

Gündəlik çörək pulu çxxarmaq üçün Bülbül gah limanda hambalhq edir, gah evlərdə qab yuyur.. (Bünyadzadə, 2005: 81).

Kirh gün ellí gün yatıya giderlerdí gelírlerdí, hamballarn vardı (174).

\subsubsection{1. Ünsüz Düşmesi}

3.1.11.1. $\varnothing</ \mathbf{y}-/$

Yanında dar ünlü bulunan sözcük başı $/ y /$ sesinin düşmesi, Azerbaycan Türkçesinde görülen karakteristik bir ses olayıdır (Kartallığlu ve Yıldırım, 2007: 182). Söz başında /y/ sesinin düşmesi olayı, Azerbaycan Türkçesinin etki alanında bulunan doğu grubu ağızlarında da görülmektedir. Urfa Merkez ağzında da kimi sözcüklerde yanında dar ünlü bulunan sözcük başı $/ y /$ sesi düşebilmektedir. 


\section{Azerbaycan Türkçesi:}

üz (< yüz): Mən qəm içrə qərq olub, qaldım ərman içində, / ̈̈züm qara, dilim lal, dostü düşman içində (Nəfəs, 2010: 96).

itir- (< yitir-): İndi başa düşürəm ki, əsgərliyə qədər çox vaxt itirmişəm (Bünyadzadə, 2005: 159).

uca (< yüce): Xalqa onun kar etmadi qazəbi bir an, / Güldü hərə bir tərəfdən daha ucadan (Vazeh, 2004: 52).

ürək (< yürek): O seni ürəkdən istayən bir ana kimi məndən də çox savindi (Məmmədquluzadə, 2004: $370)$.

\section{Urfa Merkez Ağzı:}

ürek (< yürek): A aġama sölim, ben bah̆tım bunları dínliye dínliye bením üregím şişti (155).

igit (< yiğit): Merdivana / Sarll çı ḩ merdivana / Yar semah igit karl / Ne bílír her divana (162).

üzík (< yüzük): Üzík gètírírler, bilezık gèttírírler, altun gèttírírler, elbiselıh gèttírírler (199).

üz (< yüz): O duvaġı örttíse, süsledílerse og̀lan evínden ḳattiyen o gelínín üzíní daha kimse göremez (198).

Bunun dışında aşağıdaki örnekte, iç sesteki /y/ sesinin Azerbaycan Türkçesi ile Urfa Merkez ağzında düştüğü tespit edilmiştir.

kef (< Ar. keyf):

Sağhq ilə beş gün kef sür dünyada, / Qənimət bil bu dövranı, xocam sən (Nəfəs, 2010: 141).

è herkes bèle burada bayır dag்lar var. dag்lara giderler. kèf ehíllerí, mesela üç beş arḩadaş veya yedí sekkíz arhadaş (147).

3.1.11.2. $\varnothing</-\mathbf{f}-/$

Azerbaycan Türkçesinde, bazı yabancı asıllı kelimelerde görülen sızıcı /f/ sesinin eriyerek kaybolması olayı, Urfa Merkez ağzında az da olsa görülebilmektedir.

cüt / çüt (< Far. cuft):

Bütün Rusiyanı dolaşıb gəzsən, bir cüt gözəl ayaq tapa bilməssən (Hacızadə, 2004: 439).

Üç bacı bir olilar. Bi çüt çırıhları var (227). 
3.1.11.3. $\varnothing</$ v $/<$ b $/$

Türkçe bazı kelimelerde söz başında ve söz içinde yer alan Eski Türkçe /b/ sesi, Azerbaycan Türkçesinde önce $/ v /$ sesine dönüşmüş, daha sonra da eriyerek düşmüştür (Yalçın, 2018: 163). Azerbaycan Türkçesinde görülen bu ses olayına Urfa Merkez ağzında da rastlanmaktadır.

yuha $(<$ yufka):

Aradan bir az keçməmişdi ki, Səhnəbanının anasını yuxa üstünə apardılar (ələkbərli, 2010: 5).

Burada çoxda iri olmayan, diametri cəmisibir neçə santimetr olan yastı və yuxa lapik daşı saçilir (İsmailov, 1999: 717).

İstersen yu ha ekmekten ye், istersen ḳaşı ḩtan yẻ. Çok güzel olur (207).

\subsubsection{Eski Türkçe biçimlerin korunması}

\subsubsection{1. Ünlü genişlemesi: /ö/ $</ \ddot{\mathbf{u}} /$}

Türkçenin tarihi dönemlerine ait metinlerde, ilk hecesinde geniş ünlü bulunan bazı kelimeler, Batı Türkçesinde geniş ünlülerin daralmasıyla dar ünlüyle kullanılmaya başlamıştır. Buna karşılık Batı Türkçesinin doğu kolunu oluşturan Azerbaycan Türkçesinde, Osmanlıcada dar ünlü taşıyan bazı kelimeler, geniş ünlülü olmaya devam etmiştir (Ergin, 1993: 79).

Batı Türkçesinin doğu ve batı kolları arasında görülen bu karışık durum Anadolu ağızlarında da görülmektedir. Urfa Merkez ağzı, genel yazı dilinde dar ünlü taşıyan bazı kelimelerin geniş ünlü taşıması yönüyle Azerbaycan Türkçesiyle aynı çizgide yer alır.

\section{Azerbaycan Türkçesi:}

Evdə atam və özümden on yaş böyük qardaşım qaldı (Hacızadə, 2004: 118).

Hamı bayram etdi: “Dünyada təksən / Ey böyük şahımız sənə min əhsən!” (Vazeh, 2004: 54).

İldən bir gün ayrıld,, əlində yanar məşəl, / İldən bir gün ayrıld, bütün günlərdən gözəl (Bünyadzadə, 2005: 26).

Qara zülfün dalğa-dalğa, / Gözəl yarım, heyranı mən (Nəfəs, 2010: 24).

\section{Urfa Merkez Ağzı:}

Bíz buna böyük bir ataş yapahm. İbrahim’ ataşa atalım (141).

Bu şekíl bızı böyüttr. Heremız oldıh sekkız on nüfus (153).

Babası bah̆̄ ki, padişah bah̆ ki bu ḳızı o ḳeder gözel gözel, nasıl bi ḳz ki (249). 


\subsubsection{2. Ünsüz ötümlüleşmesi: /b-/ < /p-/}

Eski Türkçe devresinde bazı kelimelerde söz başında bulunan /b/ sesi, Türkiye Türkçesinde ötümsüzleşerek $/ p /$ sesine dönüşmüştür. Eski Anadolu Türkçesinin sonlarında başlayan bu ötümsüzleşme hadisesi, Osmanlı ve Azerbaycan Türkçelerinde farklı şekillerde cereyan etmiştir. Osmanlı sahasında / $p$ /'ye dönen bazı kelimeler Azerbaycan sahasında /b/li olarak kalmış, dolayısıyla eski şekiller korunmuştur (Ergin, 1993: 80).

Urfa Merkez ağzı, bazı kelimelerde ön sesteki /b/ sesini muhafaza etmesi yönüyle Azerbaycan Türkçesine benzer bir durum sergiler. Söz başı / $b$ / sesinin ötümsüzleşmeyerek korunması, Urfa ağzı için arkaik bir ses özelliğidir.

\section{Azerbaycan Türkçesi:}

Kim bilir, toylarda ətləri bişmiş / Köndələn sümüklər arxlara düşmüş (Çobanzadə, 2011: 93).

Üzeyir bəy yenə barmaqlarm pianonun dillərindən ayırmadan soruşdu (Mirəhmov, 2006: 82).

\section{Urfa Merkez Ăgzz:}

Firında bişen daha güzel olur. Firında bişírírsen bunın adı da işte 'ali nazik (206).

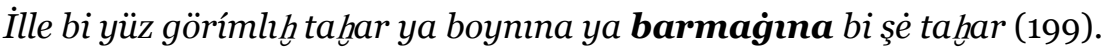

\subsubsection{3. Ünsüz ötümsüzleşmesi}

3.1.12.3.1. $/ \mathbf{k}-/</ g-/$

Eski Türkçe devresinde ince ünlü taşıyan bazı kelimelerin başındaki /k-/ ünsüzü, Batı Türkçesinde ötümlüleşerek /g-/ olmuştur. Oğuz grubunun doğu kanadını oluşturan Azerbaycan Türkçesinde ise birtakım kelimelerde bu ötümlüleşme olayı gerçekleşmemiş, eski şekil devam etmiştir. Urfa Merkez ağzında da -Azerbaycan Türkçesinde olduğu gibi- kimi kelimelerde Eski Türkçe söz başındaki /k-/ ünsüzünün korunduğu görülmektedir.

\section{Azerbaycan Türkçesi:}

O, zaman keçsə də sevgisinə xəyanət etməyən yeganə dostdur (Rihani, 2016: 67).

Onun kölgəsində nə bitki bitir, nə də heyvan yaşayır (Rihani, 2016: 91).

Günahkar uşaq kimi Nurəddinin üzünə baxıb gülümsədi (Hacızadə, 2004: 146).

Nə sünbül, nə çiçək, nə dəli könül, Nə də türküdəki o yosma qızlar (Çobanzadə, 2011: 126).

\section{Urfa Merkez Ağzı:}

Terzí evíne götírír evínde olduġı kímín işte keser (153).

Bèle gèttıh. Bi kölgeh hy yer var. Míllet orya ahnn edī(170). 
Hanı mesele balcanları ḳarnıyarı hy yaptıġmız kíbí (170).

Aḷmet paşa leglegí / gèymiş keten köynegí / keten köynek dizinde / gözí vezir ḳzında (162).

3.1.12.3.2. $/ \mathrm{t}-/</ \mathrm{d}-/$

Eski Türkçede söz başında bulunan /t-/ sesi, Oğuzcanın ilk devresi olan Eski Anadolu Türkçesinden itibaren ötümlüleşerek / $d-$ / olmaya başlamıştır. Ancak bu ötümlüleşme olayının gelişimi, Osmanlı ve Azerbaycan sahalarında farklılık göstermiştir. Osmanlıcada ötümlüleşen söz başındaki /t-/ sesi, Azerbaycan Türkçesinde bazı kelimelerde ötümlüleşmeyerek varlığını muhafaza etmiştir (Ergin, 1993: 88).

Doğu grubu ağızları içinde yer alan Urfa Merkez ağzında, Azerbaycan Türkçesinde olduğu gibi bazı kelimelerde söz başındaki / $t$ / sesinin korunduğu görülmektedir.

\section{Azerbaycan Türkçesi:}

Sonra belindən asdığı torbasından cürdəyi çıxardıb içindəki suyu kərtən-kələnin üstünə tökdü (Bünyadzadə, 2005: 83).

Nə yelkən tikməyə bir arşın iplik, / Nə yola qoymağa bir parça çəlik (Çobanzadə, 2011: 116).

Heç kəsin sağərinə tökməz inan mey bu fələk / Özü peymanəsini döndərib etmiş xunbar (Qüdsi, 2005: 257).

On günə, bir aya tikdiyin yuva / Bircə an içində dağıldl, ay quş! (Araz, 2004: 80).

\section{Urfa Merkez Ağzı:}

İnnenín delígíne bahiyam. Burdan, bun tikmissem vallahıl 'azim billahil kerim bazartesı bunun ikkísí bitmiş (154).

Bah tüfenglerínín içine barud koyilar ya. Bunu kapadilar ki tökílmesín diye (185).

\section{2. Şekil bilgisinde görülen ortak özellikler}

\subsubsection{Teklik I. ve II. kişi ekleri}

Eski Anadolu Türkçesi döneminde teklik I. kişi için kullanılan eklerden biri olan -Am, Osmanlı Türkçesinin ilk dönemine kadar geniş ünlülü olarak kullanılagelmiştir. Osmanlı Türkçesi devresinde ünlüsü daralan ekin daha sonra yuvarlak ünlülü biçimleri kullanılmıştır. Devrenin sonunda da ek, uyuma bağlanmış ve ekin günümüzdeki şekilleri ortaya çıkmıştır. Bunun yanında Eski Anadolu Türkçesi ile Osmanlı Türkçesinde -sIn biçiminde kullanılan teklik 2. kişi eki, sonradan ekin sonunda bulunan / $n$ / sesinin genizsileşmesiyle -sIñ biçimine dönmüştür (Ergin, 1993: 270).

Türkiye Türkçesinde teklik I. ve II. kişi ekleri dar ünlülü olarak kullanılırken Azerbaycan sahasında ise söz konusu eklerin, geniş ünlü taşıyan biçimleri genelleşmiştir. Urfa Merkez ağzında da zamir kökenli teklik I. ve II. kişi ekleri geniş ünlülü olarak kullanılmaktadır. 


\section{Azerbaycan Türkçesi:}

Bəy həmrahım aldırmışam əlimdən (Nəfəs, 2010: 67).

Ey yaranlar, yanmeşam mən Aycamalın dağına (Nəfəs, 2010: 73).

Qorxuram ki, vətən məndən az fayda görsün (Səid, 2006: 62).

Sən onu ən qəribə biçimdə - vaxtaşırı coşub-daşan bir şəkildə görəcəksən (Rihani, 2016: 142).

Bilirsən ki, onun üçün gətirirəm, niyə soruşursan əqdəm? (Hacızadə, 2004: 55).

\section{Urfa Merkez Ăgzı:}

Yüz ellí bèş yaşında tornn sayısını ḥatta dèdí: “Bílmiyem.” (177).

Bi parça et ahram. Bi bahuyam elektrik parası geldi (152).

Bınları a ḩşamdan ayrı ayrı suya ḳoyup islatacahsan (205).

Dorġandıhtan soyra bi bardaġa da eşkísíní hazurlarsan (204).

\subsection{2. Çokluk I. ve II. kişi ekleri}

Türkiye Türkçesinde görülen geçmiş zaman ve şart kipi dışındaki fiil çekimlerinde kullanılan çokluk I. kişi eki -Iz/-Uz, Urfa Merkez ağzında nadiren görülürken, Azerbaycan Türkçesinde görülmez. Bunun yerine Azerbaycan Türkçesinde - $\imath q /-i q$, - $u q /-\ddot{u} q$ ekleri, Urfa Merkez ağzında ise bu eklerin nispeten sızıcılaşmış biçimi olan -Ix eki kullanım sahasına çıkar.

Yine Türkiye Türkçesinde kullanılan çokluk II. kişi eki -sInIz, Azerbaycan sahasında da kullanılır. Azerbaycan sahasında bu ekin yanı sıra kullanılan -sIz eki, Urfa Merkez ağzında sözü edilen fiil çekimlerinde kullanılan tipik çokluk II. kişi ekidir.

\section{Azerbaycan Türkçesi:}

Oho, deyəsən rəsmi söhbət edəcəyik, eləmi? (Hacızadə, 2004: 358).

..silahımızı sənətkarlarımızın özlərinə layiq böyük hədəf və məqsədlərə tərəf yönəltməliyik (Vurğun, 2005: 335).

Ancaq axı biz artıq çoxdandır uşaqhq yaşından çıxmışıq (Səid, 2006: 67).

Amma heç ağ lıma da gəlmirdi ki, bu, siz olarsız... (Hacızadə, 2004: 121).

Әcaba, belə peşkəşin qəbul olmadığı nə səbəbdür və niyə məndən gizləyirsiz? (Xudiyev, 2012: 438).

Bilirsiz, insan da metal kimi bir şeydir.. (Hacızadə, 2004: 171).

\footnotetext{
Adres $\mid$ Adress 


\section{Urfa Merkez Ăgzı}

Ayahta gidip geliyih. Ögrenmişı̆hbi kere (155).

‘Abdılla abè var, Eskíden berí tamışiyıh (169).

Deyi: "Evdeyı hu, sízí beklerı h. Hoş bi ne‘met yanı.”(155).

Bení o ḳeder ḳonıştırdīz, teybe mí, alísız, ne edisíz? (150).

Ekmegímí niye alacahsız babam? (150).

\subsection{3. Şimdiki zaman eki}

Eski Türkçede şimdiki zaman kipinin çekiminde, Türkiye Türkçesinde geniş zaman çekiminde kullanılan -r, -Ir, -Ur ekleri kullanılmıştır (Türk, 1999: 291). Oğuzcanın yazıya geçirilmiş ilk dönemi olan Eski Anadolu Türkçesinde şimdiki zaman çekimi için, geniş zaman eklerinin yanında özel bazı şekiller de ortaya çıkmıştır. XV. yüzyıldan itibaren yort- fiilinin ekleşmesiyle -yor eki, yazı dilinde görülmeye başlamıştır (Türk, 1999: 304). Türkiye Türkçesinde yorl- filinden ekleşen -yor eki şimdiki zaman çekiminde genelleşirken Azerbaycan sahasında Eski Türkçenin devamı niteliğinde dar ünlülü $I r,-U r$ ekleri şimdiki zaman için kullanılagelmiştir.

Anadolu ağızlarında şimdiki zaman eki, bölgelere göre farklılık gösteren eklerin başında gelir. Doğu grubu ağızlarında şimdiki zaman için -r/-Ir, -Ar, -yer gibi farklı ekler kullanılır (Özek, 2012: 1753). Doğu grubu ağızları arasında yer alan Urfa ağzı, dar ünlülü -i $(<-I r)$ ekini kullanması yönüyle Azerbaycan Türkçesiyle benzer bir durum ortaya koyar.

\section{Azerbaycan Türkçesi:}

Gəlirəm yazmă̆a bir kəlmə, tutursan əlimi (Xudiyev, 2012: 568).

Hər tərəfə baxaram, ancaq onun şəklini görürəm (Vazeh, 2004: 66).

Boylantam, soruşuram, uşaq səsləri (Araz, 2004: 44).

\section{Urfa Merkez Ağzı:}

Üstte çıhisan seyredisen bí tene de uyanıḩ bah̆tım geldi (170).

Diyem ulan ben bu adamı taniyam (167).

Mesele bíz her sene üç yüz kilo biber aliyıh̆ (203).

\subsection{4. İstek kipi çekimi}

Batı Türkçesinde $-A$ ekiyle yapılan istek kipinin Eski Anadolu Türkçesinden sonra çokluk I. kişi, Osmanlıcanın sonlarında ise teklik I. kişi çekiminin kullanımdan düşmesiyle Türkiye Türkçesine yalnız ikinci ve üçüncü kişi çekimleri geçmiştir. Kullanımdan düşen teklik ve çokluk birinci kişi istek eklerinin işlevini ise emir ekleri üstlenmiş̧tir (Ergin, 1993: 294). 
Azerbaycan Türkçesinde istek kipinin çekiminde eski biçim devam etmiş ve $-A$ eki bütün şahıslar için kullanılmıştır. Aynı durum doğu grubu ağızları içerisinde yer alan Urfa Merkez ağzı için de söz konusudur. Urfa ağzı, özellikle istek teklik ve çokluk I. kişi çekimi açısından Azerbaycan sahasını andıran bir görüntü sergiler.

\section{Azerbaycan Türkçesi:}

Vədeyi-vəslində dedin, gündə qurbanın olam (Nəfəs, 2010: 90).

Sevdiyim, hər sözünə, sözlə, şirin canı verəm (Nəfəs, 2010: 69).

“Gəl, - dedin. - Gedək birlikdə / Heç nə durdurmaz bizi bu dünyada” (Zanet, 2010: 94).

Məsələn, "Sevdama" şeirinə baxaq (Zanet, 2010: 6).

\section{Urfa Merkez Ağzı:}

Başımı èndíriyem ki o baştan erken ḳaham (154).

Eger mümkünse bi göríşah, onl görah (169).

Artıh̆uzatmıyah. O dog̀ıī bi oğlan (251).

\subsubsection{Emir kipi çekimi}

Türkiye Türkçesinde emir kipi çekiminde her şahıs için farklı ekler kullanılır. Aynı durum Azerbaycan Türkçesi için de söz konusudur. Türkiye Türkçesinde emir teklik I. kişi çekiminde için -AyIm eki kullanılırken Azerbaycan Türkçesinde - $(X) m$ eki kullanılır. Urfa Merkez ağzında da emir teklik I. kişi çekiminde büzüşme yoluyla ortaya çıkan $-(X) m \quad(<-$ AyIm) ekinin yaygın olarak kullanıldı̆̆ görülmektedir (Özçelik, 1997: 103).

\section{Azerbaycan Türkçesi:}

Qoy səhər açılsın, səni boşuyum (Әsgərli, 2006: 140).

Sənsən, səni görüm böyümə, bitmə (Çobanzadə, 2011: 114).

Ha deyirəm yazm, imkan tapa bilmərəm (Hacızadə, 2004: 148).

Neçin deyim ki ürəyim al qandır? (Qüdsi, 2005: 188).

\section{Urfa Merkez A ̆gzı:}

Hele síz otturn, ben $\mathbf{k a h g m ~ b u ~ k i l i ́ d l e r i ́ ~ a l ı m , ~ g i d i ́ m , ~ s o r m m ~ ( 2 2 7 ) . ~}$

Bi de burg̉ulsız bi yimegímízí anlatm (206).

O gèttígí kímín gelím siye sarılım (249). 
Ya sabur ya Allah boş gètmim (246).

\subsection{6. Şart birleşik çekimi}

Türkçede fiillerin birleşik çekiminde kişi eki, kip eklerinin sonunda yer alır. Gerek doğu grubu Anadolu ağızlarında gerekse Azerbaycan Türkçesinde bu yapının değiştiği durumlar vardır. Özellikle şart birleşik çekiminde kişi ekinin şart ekinden önce gelmesine hem Urfa Merkez ağzında hem de Azerbaycan Türkçesinde yaygın rastlanmaktadır.

\section{Azerbaycan Türkçesi:}

Bozbaşdan doymaq istəyirsənsə, qonaqların tox yola salmaq istəyirsənsə, çölməyə çox ət sal (Xudiyev, 2012: 212).

Әgər buпu пәzərdə tutursansa... (Səid, 2006: 43).

İlyas bəy, sən burada qalirsansa, mən də qaliram (Səid, 2006: 201).

Səyyah oluramsa, göz işlədikcə (Araz, 2004: 30).

Ləzzətli şey bişirmək istəyirsənsə, seriallara az bax, idman zallarında az avaralan (Mirəhmov, 2006: 301).

\section{Urfa Merkez A ̆gzı:}

Ben ḳonışmışsamsa ödemag்a gelmíşem (153).

Eger babay varsa, beni babaya alacahsansa ya sabur ya Allah (192).

Bu sarayın üçte biríní biye verísense (185).

Kimi arisansa burda, ḳapıları açıg bırah̆n (171).

\subsubsection{Ek fiil geniş zaman teklik I. ve II. kişi çekimi}

Türkiye Türkçesinde ek fiilin geniş zaman teklik I. ve II. kişi çekimlerinde düz-dar ünlüler kullanılır. Azerbaycan Türkçesinde ise birinci tip kişi eklerinin kullanımında olduğu gibi düz-geniş ünlüler tercih edilir. Urfa Merkez ağzı, ek fiil geniş zaman teklik I. ve II. kişi çekimlerinde düz-geniş ünlüleri kullanması yönüyle Azerbaycan sahasına yaklaşır.

\section{Azerbaycan Türkçesi:}

Mən yanındayam, həmişə yanmdayam, dedim (Elçin, 2005: 42).

Dostlar süfrəsində doymazam, acam (Araz, 2004: 157).

Üzüntülü ömürdən çox uzaqsan, çox uzaq (Araz, 2004: 187).

Bütün pedaqoji metodlara biganəsən, çünki siniqsən (Elçin, 2005: 25). 


\section{Urfa Merkez Ağzı:}

Bah ben mesele yetmíş yaşında bi ihthyaram (182).

Anama heber èdín gülmemíş ḳzı benem (245).

Bu sıḥhatī bu uzun yaşamayī neye borçhsan (177).

Cum‘a namazında ḳyama durmuşsan, Allah’n ḥuzurındasan (183).

\subsubsection{Ek fiil geniş zaman çokluk I. kişi çekimi}

Türkiye Türkçesinde ek fiil geniş zaman çokluk I. kişi çekiminde -Iz/-Uz ekleri kullanılırken Azerbaycan

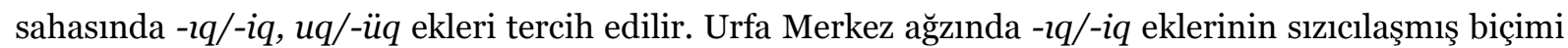
olan -Ix ekinin kullanılması, bölge ağzını Azerbaycan Türkçesine yaklaştıran bir durumdur.

\section{Azerbaycan Türkçesi:}

Dedilər, razıyıq buna hamımız, Yusifi görməkdir bizim arzumuz (Cami, 2004: 174).

Biz bir kişinin arvadıyıq, eyni vaxtda hərəmiz bir oğlan doğmuşuq (Elçin, 2005: 219).

Biz ayrı cür təmiz və ayrı cür çirkliyik (Səid, 2006: 56).

Biz Avropanın şərqində yerləşən bir ölkəyik (Səid, 2006: 96).

\section{Urfa Merkez Ağzı:}

Bíz nemeḥremıh̆, bíz göze görínemenı h (229).

Elbisesí yoh, başörtísí yoh, bíz feḳirnh (248).

Bíz evlatlaryı h, yapmaz mıyı h? (152).

\subsubsection{Zarf-fiil eki: -AndA}

-GAn sıfat-fiil eki ve -DA bulunma durumu ekinden meydana gelen -GAndA zarf-fiil eki (Bayraktar, 2004: 222), Batı Türkçesinde / $g /$ sesinin düşmesiyle Eski Anadolu Türkçesinde -Anda biçiminde kullanılmıştır. Türkiye Türkçesinde görülmeyen -AndA eki, Azerbaycan Türkçesi ile Azerbaycan Türkçesi etkisinin hissedildiği doğu grubu ağızlarında yer alan Urfa Merkez ağzında da görülmektedir.

\section{Azerbaycan Türkçesi:}

Bakıdakı evimizin damından baxanda həyat çox gözəl və yüngül idi (Səid, 2006: 11).

Bəli, asil aşiq odur öz yarmı görondə / varhğını unudaraq dili düşsün kəməndə (Qüdsi, 2005: 153).

Çöldə qar yăganda qar dənəciklərinin nazlana-nazlana uçmasına baxıb sevinərdik (Bünyadzadə, 2005: 4). 


\section{Urfa Merkez A ̆gzzı:}

"Babam çıh̆anda ḳapī çek.” dèr (229).

Egílíp su alanda, elide tas olaydım (202).

Ġerib bülbül ötende / geriblıh yaman olur (242).

\subsubsection{0. İsimden isim yapma eki: $+C I$}

Meslek ve uğraş adları yapan $+C I$ isimden isim yapma ekinin, Azerbaycan Türkçesinde ötümlü şekli kullanılmamaktadır (Buran ve Alkaya, 2011: 63). Urfa Merkez ağzında ise $+C I$ ekinin ötümlü ya da ötümsüz şeklinin kullanımında kesin bir kural bulunmamaktadır (Özçelik, 1997: 68). Ancak, ünlü ve ötümlü ünsüzle biten kelimelerde kimi zaman ünsüz uyumuna aykırı bir şekilde ekin ötümsüz biçiminin kullanılması Azerbaycan Türkçesiyle benzerlik göstermektedir.

\section{Azerbaycan Türkçesi:}

Tale olur neçə xöşbəxt insana, / Bələdçilər yolçulara, karvana (Bünyadzadə, 2005: 62).

Mənəviyyatımızı iş̧̆al etməkdə olan yabançı meyillər Qarabağ müharibəsinin xalqmıza vurduğu zərbələr qədər sarsıdıcıdır (Mirəhmov, 2006: 176).

Bir qoca dəmirçi qulınc naxışlar, / Yazar dəstəyinə “İnsan vüqarı” (Araz, 2004: 127).

\section{Urfa Merkez Ăgzı:}

Furmeçdan bi ekmeg aldım, yav bahtım, la bu ka ke keder ya (156).

Kaḥveçi dèr ya sen yanı èyí atdan aynaram dèrsen, bu at nasıl bi at? (218).

Bègím gelmiye çin, bègím dèyi ki heç bi yabançı ḳapıdan içerí adımını atmıyaca h̆ (231).

Yara benden / Oh senden yara benden / Yolçı yoliya ḳurban / Selam èt yara benden (241).

\section{Sonuc}

XVII. yüzyılda iki kola ayrılan Batı Türkçesinin doğu kolunu oluşturan lehçelerden biri de Azerbaycan Türkçesidir. Azerbaycan Türkçesi, başta Azerbaycan olmak üzere Güney Kafkasya, Kafkas Azerbaycan’ı, İran Azerbaycan'ı, Kerkük ile Irak-Suriye bölgelerindeki Türklerin dillerini içine alır. Anadolu sahasında genel olarak Batı Oğuzca hâkim olmakla birlikte Anadolu'nun doğu ve güneydoğu bölgelerinde Azerbaycan Türkçesinin etkileri görülmektedir. Güneydoğu Anadolu bölgesinde yer alan Urfa Merkez ağzı, bulunduğu konum itibarıyla Azerbaycan ve Irak-Kerkük Türkmen Türkçesine benzer özellikler sergiler.

Bu çalışmada Urfa Merkez ağzı ile Azerbaycan Türkçesi arasında bir karşlaş̧tırma yapılarak her iki dil bölgesinde görülen ortak özellikler ortaya konmuştur. 
1. Ünsüz ikizleşmesi, söz başında / $y$ / sesinin düşmesi ve söz içinde görülen göçüşme olayları Azerbaycan Türkçesi ile Urfa Merkez ağzı arasında, ses bilgisi açısından görülen ortak özelliklerin başında gelmektedir.

2. Ön seste görülen $/ d-/</ t-/$ ötümlüleşmesi ile ön seste ve iç seste görülen $/ h /</ k /$ sızıcllaşmaları, Urfa Merkez ağzı ile Azerbaycan Türkçesi arasında ortak olan ses bilgisi özellikleri arasındadır.

3. Arapça ve Farsça alıntı kelimelerde görülen artlılaşma ve önlüleşme olayları ile bu olaylar sonucu kalınlık-incelik uyumunun Türkiye Türkçesi standart yazı dilinden daha ileri bir durumda olması, Urfa Merkez ağzıyla Azerbaycan Türkçesini aynı çizgide buluşturan diğer bir ses bilgisi özelliğidir.

4. Ses bilgisi açısından Azerbaycan Türkçesiyle Urfa Merkez ağzında tespit edilen ortak unsurlardan biri de ön seste $/ k /$ ve $/ b /$ seslerinin korunarak Eski Türkçeden gelen biçimlerin devam ettirilmesidir.

5. Şekil bilgisi açısından, zamir menşeli teklik I. ve II. kişi eklerinin Türkiye Türkçesi standart yazı dilinden farklı olarak geniş ünlülü olarak kullanılması, Urfa Merkez ağzı ile Azerbaycan Türkçesi arasındaki en belirgin ortak özelliktir.

6. Türkiye Türkçesinde istek kipinin teklik ve çokluk 1. şahıs çekiminde emir ekleri kullanılırken, Azerbaycan Türkçesi ile Urfa Merkez ağzında Eski Anadolu Türkçesinde olduğu gibi - $A$ eki kullanılmaya devam etmektedir.

7. Şekil bilgisine yönelik olarak Urfa Merkez ağzı ve Azerbaycan Türkçesi arasında tespit edilen ortak özelliklerden biri de şart birleşik çekiminde kişi ekinin şart ekinden önce gelmesidir.

8. Azerbaycan Türkçesinde şimdiki zaman çekiminde -yor ekinin kullanılmaması, bunun yerine Türkiye Türkçesinde geniş zaman çekiminde kullanılan dar ünlülü -Ir, -Ur eklerinin kullanılması bu lehçe ile şimdiki zaman çekiminde dar ünlülü ekleri $(-i<-I r)$ tercih eden Urfa Merkez ağzını birbirne yaklaştıran ortak şekil bilgisi özelliklerinden biridir.

9. Azerbaycan sahasında oldukça yaygın olan -AndA zarf-fiil eki, Urfa Merkez ağzını şekil açısından Azerbaycan Türkçesine yaklaştıran bir başka ortak unsurdur.

Kitle iletişim araçlarının insan hayatına girmesi ile ağızlar ve standart yazı dili arasındaki farklar azalmaya başlamıştır. Bununla birlikte yerel konuşma biçimlerini kullanan insan kitlesinin genellikle yüksek yaş aralığına mensup kişilerden müteşekkil olduğu düşünüldüğünde ağızların zaman içerisinde kaybolma tehlikesiyle karşı karşıya kalacağı muhakkaktır. Anadolu ağızları, gerek Türk dilinin söz varlığı açısından gerekse tarihi süreç içerisinde yaşadığı gelişme ve değişmeleri tanıklayabilmesi açısından önemlidir. Türkiye Türkçesi ağızlarının bütünüyle incelenmemiş olması ağız atlaslarının hazırlanmasında engel oluşturmaktadır. Ağız bölgelerinin dil özelliklerinin ortaya konmasıyla birlikte, Türk dili araştırmalarında karşılaşılan birçok problem çözüme kavuşturulacağı gibi ağız atlaslarının hazırlanmasında da önemli bir aşama geçilmiş olacaktır. Bu bağlamda, ağızların ayrıntılı dilsel analizlerinin yapılması, farklı ağız ve lehçelerin ilgili ağız bölgesi üzerindeki etkisinin belirlenmesi, ağız atlaslarının hazırlanması sürecine katkı sağlayacaktır.

\section{Kaynakça}

Acaloğlu, A. ; Bəydili, C. (2005). Әsatirlər, Әfsanə və Ravayətlar. Bakı: Şərq-Qərb.

Altayl, S. (2018). Azerbaycan Türkçesi Sözlüğü. Ankara: Türk Dil Kurumu. 
Araz, M. (2004). Seçilmiş Әsərləri. Bakı: Lider Nəşriyyat.

Aslan, A. (2017). Şanhurfa Kültür ve Turizm Rehberi. Şanlıurfa: Şanlıurfa Valiliği İl Kültür ve Turizm Müdürlüğü.

Bakıxanov, A. (2005). Seçilmiş Әsarlari. Bakı: Avrasiya Press.

Bayraktar, N. (2004). Türkçede Fiilimsiler. Ankara: Türk Dil Kurumu.

Buran, A., Alkaya, E. (2017). Çağdaş Türk Lehçeleri. Ankara: Akçă̆.

Buran, A., Alkaya, E. (2011). Çağdaş Türk Yazı Dilleri I. Eskişehir: Anadolu Üniversitesi.

Bünyadzadə, Ü. (2005). Sənin Oxşarın Bənövşədi. Bakı.

Cami, ә. (2004). Yusif və Züleyxa. Bakı.

Cəfərzadə, Ә. (2005). Azəbaycan Qadın Şairləri Antologiyası. Bakı: Avrasiya Press.

Çobanzadə, B. (2011). Seçilmiş Şeirlari. Bakı: TÜRKSOY Kitabxanası seriyası: 20.

Elçin, (2005). Seçilmiş əsərləri. 10 Cilddə 1-ci Cild, Bakı: Çinar-Çap Nəşriyyatı.

Ergin, M. (1993). Türk Dil Bilgisi. İstanbul: Bayrak/Yayım/Basım.

Ergin, M. (1971). Azerî Türkçesi. İstanbul: İstanbul Üniversitesi Edebiyat Fakültesi.

Әsgərli, Z. (2006). Azərbaycan Nəsri Antologiyası. Beş Cilldə I Cild, Bakı: Şərq-Qərb.

Әziz, ə. (2010). Azərbaycan Folkloru Külliyyatı. XVIII Cild, Dastanlar VIII Kitab, Bakı: Folklor İnstitutu.

Hacizadə, Ә. (2004). Әsərləri. X Cilldə V Cild, “Vəfalım Mənim”, Bakı: Nafta Press.

Xudiyev, N. (2012). Səçilmiş Әsərləri. Bakı.

İsmayilov, H. ; əziz, ə. (1999). Azərbaycan Folkloru Külliyyatı. Bakı: Səda Nəşriyyatı.

Kafesoğlu, İ. (1972). Selçuklu Tarihi. İstanbul: Milli Eğitim Basımevi.

Karaağaç, G. (2012). Türkçenin Ses Bilgisi. İstanbul: Kesit.

Karahan, L. (1996). Anadolu Ağızlarının Sinıflandırılması. Ankara: Türk Dil Kurumu.

Kartallıŏlu, Y.; Yıldırım, H. (2007), “Azerbaycan Türkçesi” (Editör: Ahmet Bican Ercilasun), Türk Lehçeleri Grameri. Ankara: Akçağ.

Kürkçüoğlu, K. E. (1991). Urfa A ğzı. Ankara: Türk Dil Kurumu.

Məmmədquluzadə, C. (2004). əsərləri. Dörd Cilddə, IV Cild, Bakı: Öndər Nəşriyyat.

Mirəhmov, H. (2006). Bir Gecənin Sehri. Bakı: Nurlar Nəşriyyat və Poliqrafiya Mərkəzi.

Nəfəs, M. (2010). Bu Məkana Gəlmişəm. Bakı.

Özçelik, S. (1997). Urfa Merkez Ağzı. Ankara: Türk Dil Kurumu.

Özek, F. (2012). “Türkiye Türkçesi Doğu Grubu Ağızlarında Şimdiki Zaman Ekleri”, Turkish Studies, 7/1, s. 1751-1765.

Özkan, N. (2000). Türk Dilinin Yurtları. Ankara: Akçağ.

Rihani, Ә. (2016). Seçilmiş İncilar. Bakı.

Rza, R. (2010). Seçilmiş Әsərlər. II Cild, Bakı: Letterpress.

Sabir, M. ə. (2004). Hophopnamə. İki Cillddə I Cild, Bakı: Şərq-Qərb.

Saray, M. (1993). Azerbaycan Türkleri Tarihi, İstanbul: Nesil.

Səid, Q. (2006). əli və Nino. Bakı: Şərq-Qərb. 
Türk, V. (1999). "Türkçede Şimdiki Zaman Kavramı, Çekimleri ve Ekleri”, Türk Dünyası Araştırmaları, s. 291-340.

Yalçın, S. K. (2018). Azerbaycan Türkçesi Grameri. İstanbul: Kesit.

Vazeh, M.Ş. (2004).Nəğmalar. Bakı: Şərq-Qərb.

Vurğun, S. (2005). Seçilmiş Әsərləri. Beş Cilddə V Cild, Bakı: Şərq-Qərb.

Zanet, T. (2010). Ana Dilim. Bakı. 